\title{
MEETING PUBLIC EXPECTATIONS WITH ECOLOGICAL INNOVATION IN RIPARIAN LANDSCAPES ${ }^{1}$
}

\author{
Joan Iverson Nassauer, Sandra E. Kosek, and Robert C. Corry ${ }^{2}$
}

\begin{abstract}
Appearances matter for managing riparian landscapes because the appearance of landscapes affects public willingness to accept plans and designs that improve ecological quality. Riparian landscape design and planning should respect and strategically incorporate characteristics that the public values and expects to see. Such design can be quite novel in its ecological effects, but it also should be sufficiently familiar in appearance to correspond with cultural values. This paper describes some influential cultural values for riparian landscapes and demonstrates how attention to such values supports public acceptance of ecologically innovative design in rural and urban watersheds.

(KEY TERMS: culture; design; landscape ecology; land use planning; riparian; watershed management.)
\end{abstract}

\section{RIPARIAN LANDSCAPE BEAUTY: PUBLIC EXPECTATION}

Appearances matter for managing riparian landscapes because appearances affect public willingness to accept landscape plans that improve ecological quality. Design and planning for landscape change and management should begin by querying what is ecologically beneficial, but it should not prescribe action before systematically investigating how people expect the landscape to look and what they value in its appearance. Human expectations direct landscape change. Our everyday ways of thinking about and seeing the landscape - what we like, what we want, and what we think others approve of - can create opportunities for ecological innovation, or it can assure that important ecological insights go unused or are undermined by old habits or assumptions. For beneficial landscape change to be sustained in our culture of politics, real estate, and pride of ownership, what people perceive as valuable about the landscape must be respected. Then, it can be used as a springboard for change (Nassauer, 1997).

Appearances are particularly influential for the management of riparian landscapes because people often expect streams to be beautiful. Both centuries old, Western landscape design traditions and contemporary empirical landscape perception research confirm the aesthetic appeal of rivers as a landscape element. Curving streams were valued as elements of 18th century English landscapes that introduced the same picturesque landscape aesthetics we perpetuate today (Levin, 1977; Robinson, 1991). Landscapes that lacked streams were enhanced by works of engineering that were made to look like "natural" streams most desirably including a picturesque curve, some bubbling water, and stony banks (Bonsignore, 1992). Today these same picturesque characteristics are described in scientific terms - as a floodplain for a stream meanders or riffles in the stream - and they are valued by scientists for their ecological benefits (Rosgen, 1996). However, it is the enduring aesthetic appeal of the stream that leads the public to see its value. Even aquatic ecologists may have enjoyed the aesthetic qualities of streams long before they became scientists (Gorham, 1997).

Over the past 30 years, empirical investigations have shown that oceans, lakes, streams, and even ponds are consistently associated with human perceptions of landscape beauty. From the beginning of 20th century, efforts to quantify landscape aesthetics, rivers have been preeminent. The first contemporary system to evaluate landscape aesthetics was Leopold's (1969) effort to quantify the aesthetic characteristics

1Paper No. 01008 of the Journal of the American Water Resources Association. Discussions are open until August $1,2002$.

2Respectively, Professor and Ph.D. Students, School of Natural Resources and Environment, University of Michigan, Dana Building, 430 East University, Ann ARbor, Michigan 48109-1115 (E-Mail/Nassauer: nassauer@umich.edu). 
of the Hell's Canyon of the Snake River. His system placed higher values on reaches that included white water or had good water clarity. What people typically value about the appearance of rivers is the clarity of the water and the presence of trees, and hills or bluffs along their valleys (Zube et al., 1974; Smardon, 1983; Nassauer, 1995a). People tend to agree that streams that look muddy, smell, carry dying fish or trash are ugly (House and Sangster, 1991; Gregory and Davis, 1993; Ryan, 1998).

What people tend to disagree on is control. The ecological benefits of riparian landscape characteristics do not assure that they will be perceived as valuable. For example, while a stream that meanders in its own floodplain and includes woody debris may look attractive to hydrologists, Midwestern farmers tend to appreciate the look of a stream that has been engineered as straight channel with "nothing in the way" - no trees or debris to clog the quick flow of water from their fields (Nassauer, 1988; Rosgen, 1996). Gregory and Davis (1993) found that the British public also prefer channels unimpeded by woody debris. Only a subsample of more environmentally knowledgeable geography professors tended to prefer the more "natural" river scenes. House and Sangster (1991) also found that the British prefer maintained features along river banks compared with more "natural" features: for example, mown grass compared with tall grass. Surveying rural residents of southeast Michigan, Ryan (1998) found that, compared with nonfarmers, farmers had significantly lower preferences for living near a river. Instead, they preferred a mown yard and living near cultivated land.

Even when people disagree on the degree of apparent control that is desirable within the river corridor, the idea of naturalness of the river itself is highly valued (House and Sangster, 1991; Gregory and Davis, 1993; Manning, 1997; Ryan, 1998). In an urban context, even an obviously polluted river may be seen to represent nature. For example, Gobster and Westphal (1998) found that rivers throughout the city of Chicago were appreciated for their natural beauty. Only the Chicago rivers with heavily industrialized banks were seen as less healthy and less beautiful, and even these continued to attract anglers, boaters, and other recreational users.

\section{DIFFICULTIES AND OPPORTUNITIES FOR ECOLOGICAL INNOVATION}

That rivers are so widely recognized for their beauty makes them both especially difficult and especially opportune places to innovate for ecological benefits. What is difficult about introducing ecological innovation is that much can be ecologically compromised about a river, and yet, the public still perceives the river as beautiful; the problem may not be recognized (Nassauer, 1992). Our need for natural beauty may cause us to ignore the cognitive dissonance that underlies our perceptions (Yoesting, 1976). We so much want, perhaps even need, the riparian corridor to represent beautiful nature, that w/e try to forget that we should not eat the fish. We so much want to enjoy the water and wildlife, that we try not to think about the heavy metals in the sediments where the water birds walk, and we blot out the steel mills on the horizon.

For ecological innovation, what is opportune about rivers is the same as what is difficult: people perceive rivers as beautiful. Because people love the way rivers look, they notice and care about rivers. Part of the way to advance the ecological health of rivers is to get people to notice what has been undermined about their ecological health or what needs to be protected to maintain ecological health. Increasingly, this opportunity is being addressed by environmental education and volunteer citizens' monitoring of aquatic biological integrity (see, for example, Huron River Watershed Council, 2000). These and other types of environmental groups are bringing a greater degree of ecological knowledge and appreciation to an everwidening sector of the public. But even this knowledge is not enough. Not everyone notices how landscape practices influence water quality within a watershed, even if they value the aesthetic appeal of the river (Ryan, 1998).

To enhance the biological integrity of rivers, increased public knowledge needs to be augmented by culturally sustainable innovative design and planning. Cultural sustainability refers to ecologically beneficial practices that elicit sustained human attention over time. If practices are not culturally sustainable, their ecological benefits may be compromised as land ownership changes hands, as development pressures increase, or as different political viewpoints arise. How can people be moved to pay attention to and support what is ecologically beneficial? "Landscapes that are ecologically sound, and that also evoke enjoyment and approval, are more likely to be sustained by appropriate human care over the long term" (Nassauer, 1997:69). Much of what people want landscapes to be is driven by cultural traditions and social motives. If people recognize an ecologically beneficial riparian landscape as something they value and enjoy, they are more likely to keep it that way. If they don't perceive its immediate value, they are less likely to sustain it over time.

The public often does not see the value of new management regimes, plans, or designs -- particularly when new plans propose to change what is perceived 
as natural, like rivers. We like what we know, what has worked for us. When the plan is to change a landscape - whether the purpose is streambank stabilization, subdivision, or timber harvest - public acceptance is particularly critical. Regardless of who owns the land, many landscapes are perceived as public: owned in some way by all who see them. Landscape design for ecological benefit cannot afford a lapse between design innovation and public recognition. From the outset and over the long term, innovative designs require advocates and caretakers. Incorporating familiar aesthetic values into these designs can help to elicit this investment. Without it, ecological innovations may not be sustained over time.

\section{APPLICATIONS ACROSS THE WATERSHED}

In riparian landscapes, open water and trees are popularly recognized for their aesthetic value: Using the theory of cultural sustainability, these valued features can be designed in association with ecologically beneficial features that are not as widely valued, like ephemerally inundated floodplains and wetlands, and emergent plant communities. We used this strategy in our design for Phalen Wetland Park in St. Paul, Minnesota (Nassauer, 1995b), in which we designed wetlands (not widely valued by the public in the city) to locate public access points nearest areas of perennial open water (which is widely recognized as beautiful). We also used a strategy of "cues to care" in which areas that were being restored to wet meadow zone biodiversity (not widely appreciated) were planted in visibly banded patterns and the edges of pathways were mown (because signs of human care are widely appreciated). In our design for the Urban Ecology Center in North St. Paul, Minnesota (Nassauer and Bower, 1997), we created opportunities to view new wetland landscapes from elevated positions, gaining a panoramic view - another characteristic that is popularly recognized for its aesthetic value.

Each of these opportunities and related strategies has parallels that extend to the watershed. If local people know how watershed landcover patterns and management choices affect rivers, they may make ecologically beneficial choices because they care about the river. However, the many people who don't know how landcover affects rivers may embrace beneficial landcover change if new landcover patterns meet public expectations as attractive landscapes.

In a study of alternative future scenarios for agricultural watersheds, for example (Nassauer and Corry, 2000; Santelmann et al., 2001), we interviewed farmers who valued an innovative ecologically beneficial cropping pattern that they had never seen and that they perceived could have extra management costs. Why? Because they recognized the diversity of cover types, and the erosion-preventing strip pattern from land cover they had seen and valued before. The new pattern met their expectations and matched their aesthetic and stewardship values.

We investigated the landscape perceptions of urban residents in Maplewood, Minnesota, as part of a project to design innovative surface storm water management systems (Hartjen and Nassauer, 1995). Local residents were most concerned about the neat appearance of their neighborhood, and our collaborators on the city engineering staff were most concerned about water quality and quantity. Neighborhood residents did recognize that storm water management was a problem on their street, and this gave the City of Maplewood a foundation for introducing change. However, for storm water management to take the form of an innovative surface treatment system that also increased urban biodiversity, residents also had to recognize the innovation as desirable. Using the results of our interview survey, we incorporated landscape characteristics that neighborhood residents recognized as valuable into our design for the system with the City of Maplewood (Nassauer et al., 1997; Nassauer, 1999). The rainwater gardens that line the streets of the neighborhood now clean and infiltrate storm water. They also introduce native plants and greater connectivity to an urban neighborhood. Most importantly, the residents perceive the rainwater gardens lining the street with flowers and stone walls as an amenity for their homes and neighborhood. The project has become a widely emulated model.

Federal government initiatives for watershed research, stream corridor restoration, and streambank protection recognize the importance of public acceptance of innovations (U.S. EPA, 1996), and the cultural and aesthetic values of stream corridors (Natural Resources Conservation Service, 1996; Federal Interagency Stream Restoration Working Group, 1998). Public acceptance of ecological innovation is a process involving stakeholders, and it is also the topic of a growing body of more generalizable knowledge that will allow science and policy to anticipate and build on public expectations. Watershed research that incorporates stakeholder perceptions will make even greater contributions to riparian and watershed science if it intentionally continues to build the body of both theoretical and empirical knowledge of public landscape perception.

Federal guidelines for management of rivers and corridors include many practices that the public is likely to recognize for their aesthetic value (e.g., 
natural-appearing meander restoration, weirs and deflectors that generate sound and create whitewater, vegetated streambanks). If practices for streambanks and corridors were designed using landscape perception knowledge to gain broad popular acceptance, they could build on these currently recommended practices. Emerging regional initiatives are explicitly attempting to incorporate visualization tools into planning and design frameworks for agricultural and residential landscapes, recognizing that the appearance of ecological riparian management is critical to its acceptance (Bentrup et al., 2000).

\section{CONCLUSION}

Public acceptance and sustained public support for ecological innovations in riparian landscapes and watersheds can be enhanced by planning that builds on public expectations for the beauty of rivers, public appreciation of the beauty or stewardship apparent in some watershed landscapes, and increasing public knowledge of ecological phenomena. Each creates opportunities to match public values with ecological design innovation, making change more acceptable. Over the long term, as more valued ecological innovations are built into riparian landscapes, this strategy is likely to lead to higher public expectations for the ecological performance of rivers and landscapes.

Plans and designs that are firmly anchored in public expectations need not conform to expectations, giving people what they already know regardless of its ecological effect. Rather, innovative design should correspond with expectations, giving people what may be quite novel in its ecological enhancement but also sufficiently familiar in appearance to recognizably correspond with public landscape values. Such innovation sometimes can break the deadlock between economic and ecological values by replacing assumptions about hydrological and ecological effects of a given land use with culturally sustainable design innovation for that land use. This means that new designs for stream corridor engineering, or watershed residential and industrial land uses, for example, can have different, more beneficial, effects on rivers than did past forms of engineering and development. Rather than leaving policymakers or landscape scientists to work with old black and white choices of developed and undeveloped land, or natural and disturbed stream corridors, innovative design can offer new forms of urbanization, development, and agriculture, which are designed to achieve ecological goals at the same time as they reflect public and private values.

\section{ACKNOWLEDGMENTS}

We are grateful for support for this work provided by the McKnight Foundation; the Legislative Commission on Minnesota Resources; the Ramsey-Washington Watershed District; the City of Maplewood, Minnesota; the City of St. Paul, Minnesota; and the Environmental Protection Agency and National Science Foundation, Grant No. R825335-01-0.

\section{LITERATURE CITED}

Bentrup, G., M. Dosskey, M. Schoeneberger, G. Wells, T. Leininger, and K. Klenke, 2000. Planning for Multi-Purpose Riparian Management. In: Riparian Ecology and Manage:ment in Multi-Land Use Watersheds, P. J. Wigington and R. L. Beschta (Editors). American Water Resources Association, Middleburg, Virginia.

Bonsignore, R., 1992. Representing the Ecological Function of Midwestern Farm Streams: Price's Picturesque Applied to Stream Corridors. Unpublished Masters Thesis, Landscape Architecture, University of Minnesota, Minneapolis, Minnesota.

Federal InterAgency Stream Restoration Working Group, 1998. Stream Corridor Restoration: Principles, Processes, and Practices. U.S. Government Printing Office, Washington D.C.

Gobster, P. H. and L. M. Westphal, 1998. People and the River: Perception and Use of Chicago Waterways and Fecreation. National Park Service, Rivers, Trails, and Conservation Assistance Program, Milwaukee, Wisconsin.

Gorham, E., 1997. Human Impacts on Ecosystems and Landscapes. In: Placing Nature: Culture in Landscape Ecology, J. I. Nassauer (Editor). Island Press, Washington, D.C

Gregory, K. J. and R. J. Davis, 1993. The Perception of Riverscape Aesthetics: An Example From Two Hampsh.ire Rivers. Journal of Environmental Management 39(3):171-185.

Hartjen, A. and J. I. Nassauer, 1995. Aesthetic Conventions for the Ecological Retrofit of Birmingham Street. University of Minnesota, Minneapolis, Minnesota.

House, M. R. and E. K. Sangster, 1991. Public Perception of River Corridor Management. Journal of the Institution of Water and Environmental Management 5:312-317

Huron River Watershed Council, 2000. Adopt-A-Stream. Available at http://comnet.org/hrwc/adopt.htm

Leopold, L. B., 1969. Quantitative Comparisons; of Some Aesthetic Factors Among Rivers. Geological Survey Circular No. 670. USGS, Washington, D.C.

Levin, J. E., 1977. Riverside Preference: On-site and Photographic Reactions. Unpublished Masters Thesis, Natural Resources, University of Michigan, Ann Arbor, Michigan

Manning, O. D., 1997. Design Imperatives for River Landscapes. Landscape Research 22(1):67-94.

Nassauer, J. I., 1988. Landscape Care: Perceptions of Local People in Landscape Ecology and Sustainable Development. Landscape and Land Use Planning, No. 8, Amer. Soc. of Landscape Architects, Washington D.C.

Nassauer, J. I., 1992. The Appearance of Ecological Systems as a Matter of Policy. Landscape Ecology 6:239-250.

Nassauer, J. I., 1995a. Culture and Changing La.ndscape Structure. Landscape Ecology 10:229-237.

Nassauer, J. I., 1995b. Messy Ecosystems, Orderly Frames. Landscape Journal 14:161-170.

Nassauer, J. I., 1997. Cultural Sustainability. In: Placing Nature: Culture in Landscape Ecology, J. I. Nassauer (Editor). Island Press, Washington, D.C

Nassauer, J.I., 1999. Ecological Retrofit. Landscape Journal $17(2)$ :15-17. 
Nassauer, J. I. and A. Bower, 1997. The North St. Paul Urban Ecology Center: "Hands-On" Wetland Restoration for Environmental Education. University of Minnesota., Minneapolis, Minnesota.

Nassauer, J. I. and R. C. Corry, 2000. Rural Watersheds and Policy. Available at http://www.snre.umich.edu/nassauer/lab_index. html.

Nassauer, J. I., B. Halverson, and S. Roos, 1997. Bringing Garden Amenities Into Your Neighborhood: Infrastructure for Ecological Quality. University of Minnesota, Minneapolis, Minnesota.

Natural Resources Conservation Service, U.S. Department of Agriculture, 1996. Engineering Field Handbook Chapter 16: Streambank and Shoreline Protection. U.S. Government Printing Office, Washington, D.C.

Robinson, S. K., 1991. Inquiry Into the Picturesque. University of Chicago Press, Chicago, Illinois.

Rosgen, D., 1996. Applied River Morphology. Wildland Hydrology, Pagosa Springs, Colorado.

Ryan, R. L., 1998. Local Perceptions and Values for a Midwestern River Corridor. Landscape and Urban Planning 42(2-4):225-237.

Santelmann, M. V. et al., 2001. Applying Ecological Principles to Land-Use Decision Making in Agricultural Watersheds. In: Applying Ecological Principles to Land Management, V. H. Dale and R. A. Haueber (Editors). Springer-Verlag, New York, New York.

Smardon, R. C., 1983. The Future of Wetlands: Assessing VisualCultural Values. Allanheld Osmun, Totowa. New Jersey.

U.S. Environmental Protection Agency, 1996. Strategic Plan for the Office of Research and Development. EPA/600/R-96/059.

Yoesting, D. R. and D. L. Burkhead, 1976. Perception of Water Pollution in a Rural Area: A Cognitive Dissonance Approach. Iowa State Journal of Research 51:59-66.

Zube, E. H., D. G. Pitt, and T. W. Anderson, 1974. Perception and Measurement of Scenic Resources in the Southern Connecticut River Valley. Institute for Man and His Environment, University of Massachusetts, Amherst, Massachusetts. 